\title{
Serine Protease Inhibitor Attenuates Ovalbumin Induced Inflammation in Mouse Model of Allergic Airway Disease
}

\author{
Sanjay Saw, Sagar Laxman Kale, Naveen Arora* \\ Institute of Genomics and Integrative Biology, Delhi University Campus, Delhi, India
}

\begin{abstract}
Background: Serine proteases promote inflammation and tissue remodeling by activating proteinase-activated receptors, urokinase, metalloproteinases and angiotensin. In the present study, 4-(2-Aminoethyl) benzenesulfonyl fluoride (AEBSF) a serine protease inhibitor was evaluated for prophylactic and therapeutic treatment in mouse model of airway allergy.

Methods: BALB/c mice were sensitized by i.p route and challenged with ovalbumin. They were treated i.n. with 2, 10 and $50 \mu \mathrm{g}$ of AEBSF, one hour before or after challenge and euthanized to collect BALF (bronchoalveolar lavage fluid), blood and lungs. Proteolytic activity, total cell/eosinophil/neutrophil count eosinophil peroxidase activity (EPO), IL-4, IL-5, IL-10, IL-13, cysteinyl leukotrienes and 8-isoprostane were determined in BALF and immunoglobulins were measured in serum. H\&E and PAS stained lung sections were examined for cellular infiltration and airway inflammation.

Results: Mice exposed to ovalbumin and treated with PBS showed increased cellular infiltration in lungs and higher serum $\operatorname{lgE}$, IgG1 and IgG2a levels as compared to sham mice. Treatment with AEBSF reduced total cells/eosinophil/neutrophil infiltration. Both prophylactic and therapeutic AEBSF treatment of 10 or $50 \mu \mathrm{g}$ reduced serum $\operatorname{lgE}$ and IgG1 significantly $(p<0.05)$ than control. AEBSF treatment reduced the proteolytic activity in BALF. IL-4 IL-5 and IL-13 levels decreased significantly $(p<0.05)$ after AEBSF treatment while IL-10 levels increased significantly $(p<0.05)$ in BALF. Airway inflammation and goblet cell hyperplasia reduced as demonstrated by lung histopathology, EPO activity and cysteinyl leukotrienes in BALF after treatment. AEBSF treatment also suppressed oxidative stress in terms of 8-isoprostane in BALF. Among the treatment doses, 10 or $50 \mu \mathrm{g}$ of AEBSF were most effective in reducing the inflammatory parameters.
\end{abstract}

Conclusions: Prophylactic and therapeutic treatment with serine protease inhibitor attenuates the airway inflammation in mouse model of airway allergy and have potential for adjunct therapy.

Citation: Saw S, Kale SL, Arora N (2012) Serine Protease Inhibitor Attenuates Ovalbumin Induced Inflammation in Mouse Model of Allergic Airway Disease. PLoS ONE 7(7): e41107. doi:10.1371/journal.pone.0041107

Editor: Dennis W. Metzger, Albany Medical College, United States of America

Received December 28, 2011; Accepted June 20, 2012; Published July 19, 2012

Copyright: $\odot 2012$ Saw et al. This is an open-access article distributed under the terms of the Creative Commons Attribution License, which permits unrestricted use, distribution, and reproduction in any medium, provided the original author and source are credited.

Funding: The work covered in this manuscript was funded by the Council for Scientific and Industrial Reasearch (CSIR). The URL for the funder's website is "http://rdpp.csir.res.in/csir_acsir/Home.aspx". The funder had no role in study design, data collection and analysis, decision to publish, or preparation of the manuscript.

Competing Interests: The authors have declared that no competing interests exist.

*E-mail: naveen@igib.res.in

\section{Introduction}

Proteases are an important group of proteins implicated in manifestation of coagulopathies, respiratory inflammatory diseases, cancer and degenerative diseases [1-3]. Evidence shows that both intrinsic and extrinsic proteases play a major role in pathophysiology of airway diseases like asthma [4]. Proteolytic activity of allergens from fungi, pollens, animals, house dust mites and cockroaches augment allergic responses [5-9]. Furthermore, intrinsic proteases like mast cell tryptase initiates late phase allergic reactions [10].

Proteases exacerbate allergic diseases by compromising bronchial epithelial permeability $[11,12]$, disturbing protease antiprotease balance at lung surfaces, mediating cytokine release, activating PAR-2 receptors expressed by a variety of immune cells [13] and orchestrating Th-2 responses by cleaving CD23 on B-cells and CD25 on T-cells. Inactivated protease allergens have lesser potential in manifestation of allergic immune response [8]. Recently Post et al. [14] suggested that the epithelial barrier function of allergen is independent of protease activity. Targeting proteolytic activity by inhibitors can prove crucial to reduce proteases induced inflammatory diseases. Aprotinin prevented trypsin induced shock in dogs [15], chymase inhibitors SUNC8257 [16], Y-40613 [17], and SUN-8077 [18], have shown to reduce dermatitis in animal models. AEBSF is an irreversible serine protease inhibitor with broad specificity (Trypsin, chymotrypsin, plasmin, thrombin, kallikreins) and high affinity. It inactivates the enzymes under acidic inflammatory condition, is non toxic (LD50 of $76 \mathrm{mg} / \mathrm{kg}$ ), soluble in water $(200 \mathrm{mg} / \mathrm{ml})$ and excreted from the body. AEBSF is a unique molecule that can inhibit serine proteases as well as NADPH oxidase, a primary enzyme responsible for catalyzing production of ROS in epithelial cells, inflammatory cells and phagocytes [19]. Owing to these properties we hypothesized that AEBSF may reduce allergic airway inflammation. Current strategies for treatment of allergic diseases rely heavily on antihistamines and anti-inflammatory agents. The present study is therefore aimed to explore 
prophylactic and therapeutic effects of AEBSF in mouse model of allergic airway disease.

\section{Results}

\section{AEBSF Treatment Reduces Cellular Infiltration in Lung}

Mice sensitized and challenged with ovalbumin have increased infiltration of inflammatory cells in BALF as compared to sham mice. AEBSF treatment significantly reduced the cellular infiltration in the lungs of mice compared to ovalbumin group $(\mathrm{p}<0.05)$. AEBSF treatment before antigen challenge reduced the total cells/ eosinophil/neutrophil counts in a dose dependent manner (2, 10 and $50 \mu \mathrm{g}$ ) whereas the treatment after the challenge decreased maximum infiltration at $10 \mu \mathrm{g}$ of AEBSF (Figure la-c). Dexamethasone also showed significant reduction in the total cells/ eosinophil/neutrophil counts in both the treatment conditions in mice.

EPO in BALF of each treatment group was determined by ELISA (Figure 1d). AEBSF treatment reduced EPO activity in a dose dependent manner in both the treatment groups; however reduction was maximum at $10 \mu \mathrm{g}$ of AEBSF for after challenge group of mice. The reduction in EPO activity was significant in both the treatment groups at all dose of AEBSF compared to ovalbumin group. Dexamethasone treatment also reduced the EPO activity significantly in BALF $(\mathrm{p}<0.05)$.

\section{AEBSF Modulates Proteolytic Activity in BALF}

Ovalbumin sensitized and challenged mice showed increased protease activity in BALF. AEBSF treatment reduced proteolytic activity significantly, in both before and after challenge treatment groups (Figure 2). However, there was no significant reduction in protease activity in BALF of dexamethasone treated group of mice.

\section{AEBSF Lowers Mice Serum Antibody Titer}

Ovalbumin specific antibody (IgE, IgGl and IgG2a) levels were measured in the sera of mice by ELISA (Figure 3). There was a reduction in specific $\mathrm{IgE}$ but no significant decrease was observed up to $10 \mu \mathrm{g}$ of AEBSF in before challenge treatment group. Among after challenge groups, $10 \mu \mathrm{g}$ of AEBSF treated group of mice showed significant decrease in IgE titer in comparison to ovalbumin group mice. IgGl titer reduced significantly in both, before and after challenge groups of mice at $10 \mu \mathrm{g}$ and $50 \mu \mathrm{g}$ doses of AEBSF. Dexamethasone treatment also lowered the $\mathrm{IgE}$ and IgGl titer significantly $(\mathrm{p}<0.05)$. The IgG2a level was comparatively higher in before challenge treatment groups than ovalbumin sensitized and PBS treated mice (Figure 3).

\section{AEBSF Reduces Th2 Cytokines with Enhanced IL- 10 Levels}

IL-4, IL-5, IL-13 (Th2 cytokines) and IL-10 were analyzed in the BALF samples of mice by ELISA. The absolute values of cytokines in BALF were derived by the reference standard curve.

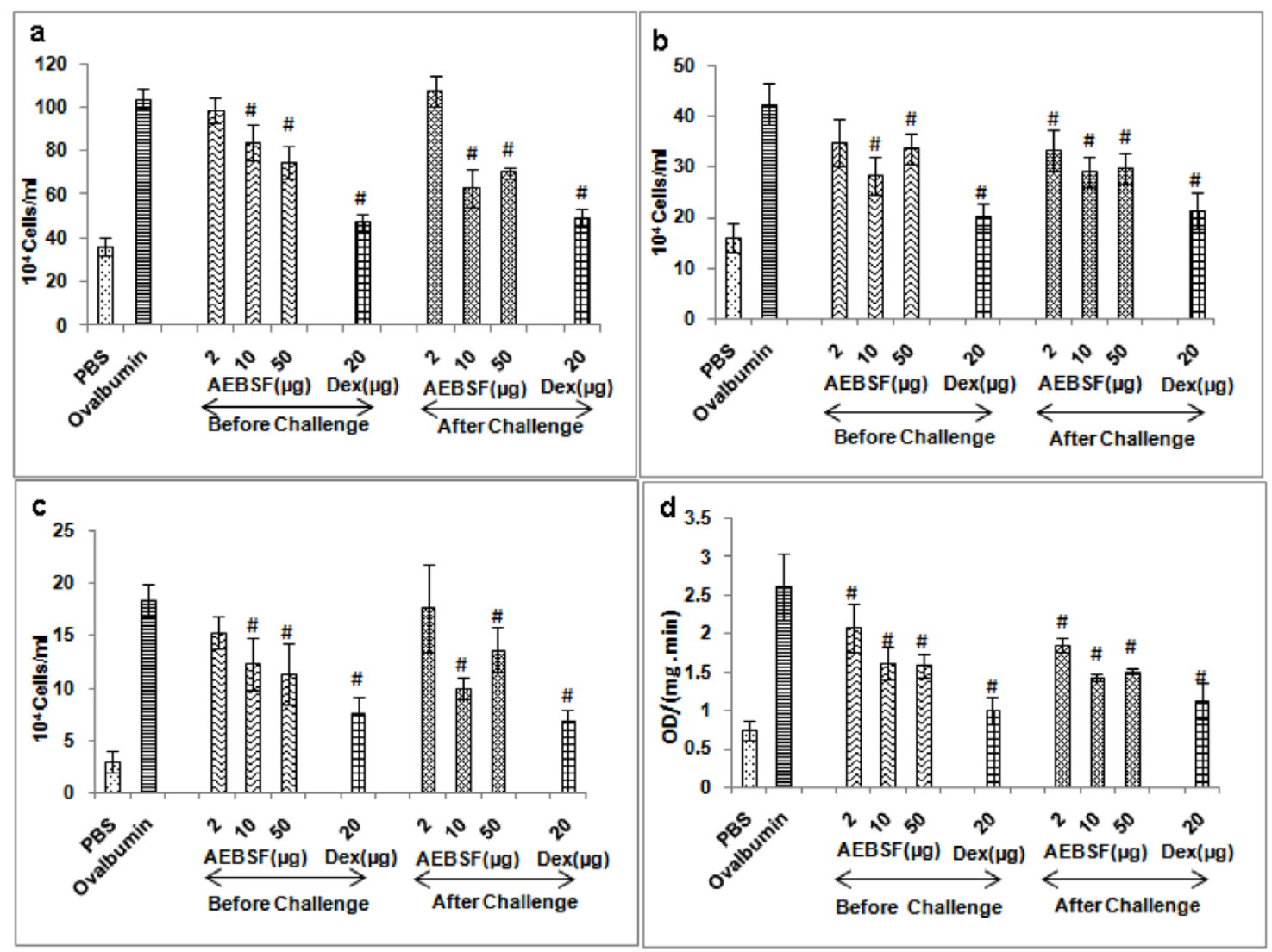

Figure 1. AEBSF/Dex (dexamethasone) treatment reduces cellular infiltration. (a) Total cell count (b) neutrophil count (c) eosinophil count and (d) EPO activity in terms of OD/(mg. min) in BALF of mice. Data are presented as mean \pm SD of 6 mice per group for one of the two independent mice experiments. \#: $\mathrm{p}<0.05$.

doi:10.1371/journal.pone.0041107.g001 


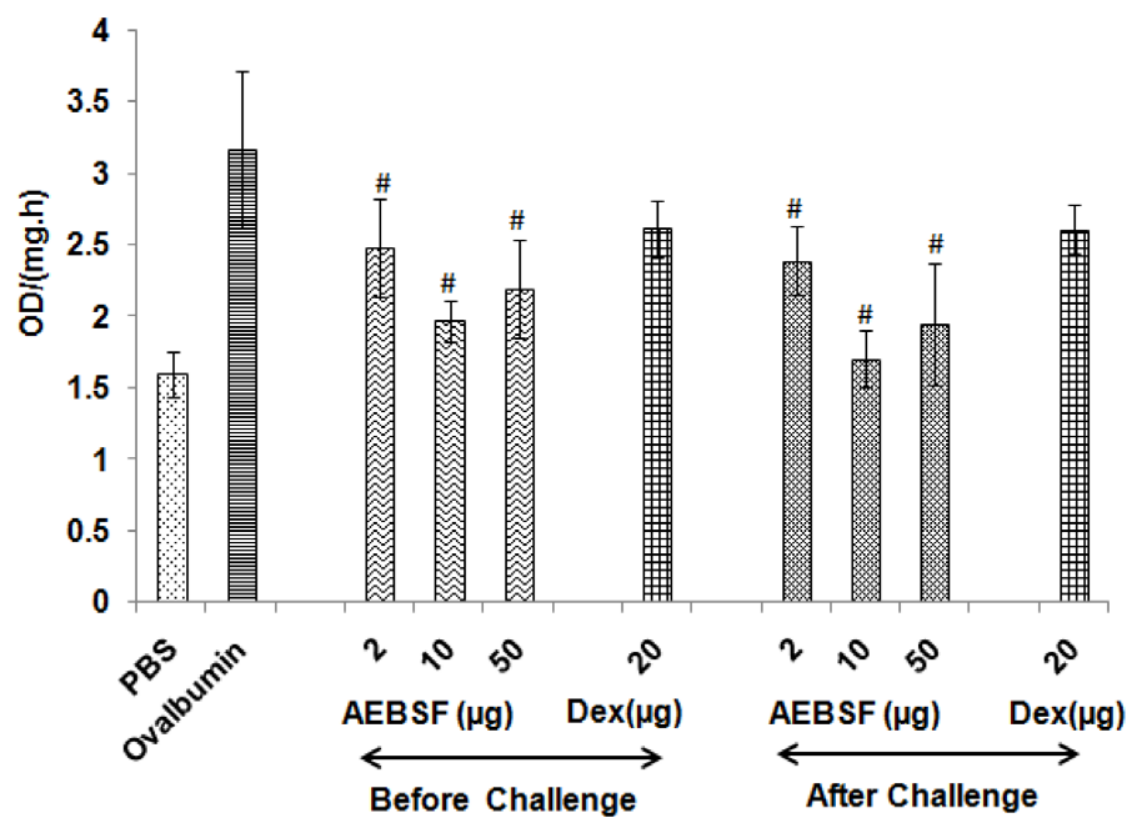

Figure 2. AEBSF reduces proteolytic activity in BALF. Proteolytic activity in term of $O D /(\mathrm{mg} . \mathrm{h})$ in ovalbumin challenged and AEBSF/Dex treated mice. Data are presented as mean \pm SD of 6 mice per group for one of the two independent mice experiments. \#: $p<0.05$.

doi:10.1371/journal.pone.0041107.g002

IL-4, IL-5 and IL-13 levels were reduced in before and after ovalbumin challenge treatment groups in a dose dependent manner (Figure 4). IL-10 level was significantly increased with higher dose of AEBSF $(50 \mu \mathrm{g})$ in both the treatment groups of mice than control. IL-13 level was significantly reduced in mice given $10 \mu \mathrm{g}$ or $50 \mu \mathrm{g}$ of AEBSF. Administration of dexamethasone reduced the Th2 cytokines (IL-4, IL-5 and IL-13) significantly $(\mathrm{p}<0.05)$ and also up regulated the IL-10 level in both the treatment conditions in mice.

\section{AEBSF Treatment Suppresses Airway Inflammation}

Lung sections of mice stained with haematoxylin and eosin revealed marked increment in peribronchial and perivascular infiltration of cells in ovalbumin group compared to PBS group. AEBSF treatment reduced the cellular infiltration in ovalbumin induced mouse model in a dose dependent manner in both before and after challenge treatment groups (Figure 5a-h). There was a significant reduction in cellular infiltration with 10 or $50 \mu \mathrm{g}$ dose of AEBSF, which was further confirmed by a reduced inflammation score both in before and after challenge treatment group of mice in comparison to the ovalbumin group (Figure 5k). PAS

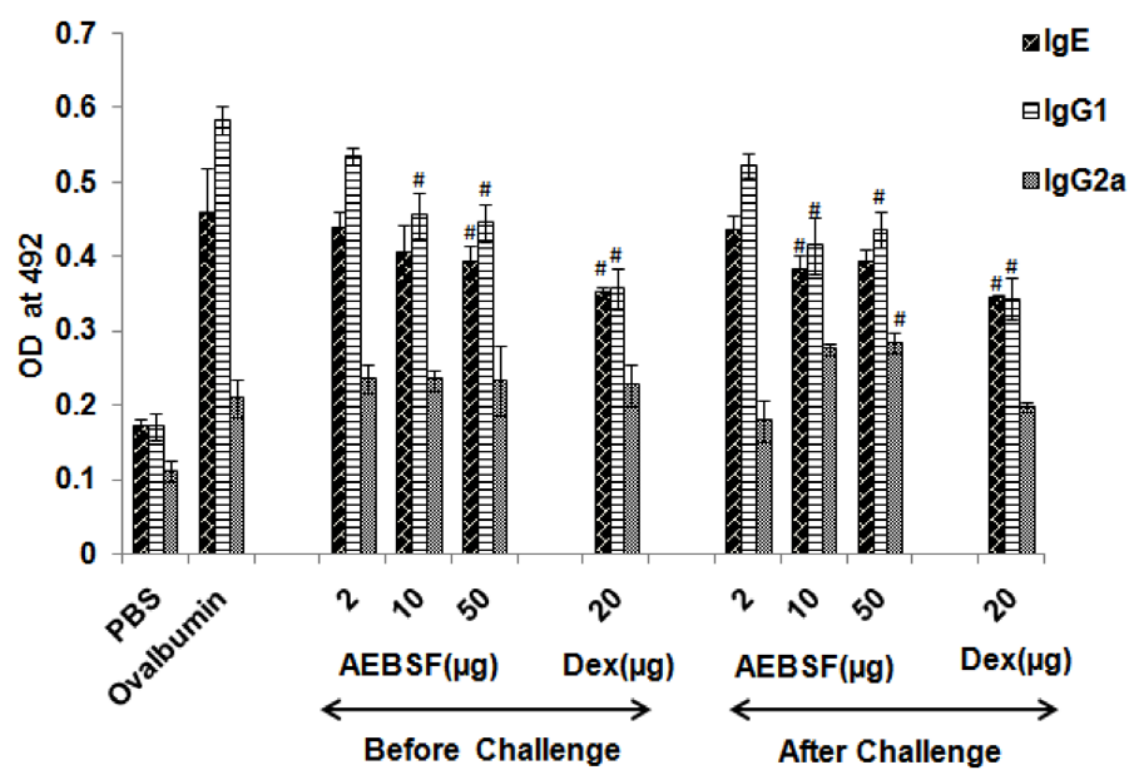

Figure 3. AEBSF/Dex modulates serum immunoglobin level. $\lg E$, lgG1 and lgG2a titer in sera of mice presented as mean \pm SD of 6 mice per group for one of the two independent mice experiments. \#: $p<0.05$.

doi:10.1371/journal.pone.0041107.g003 


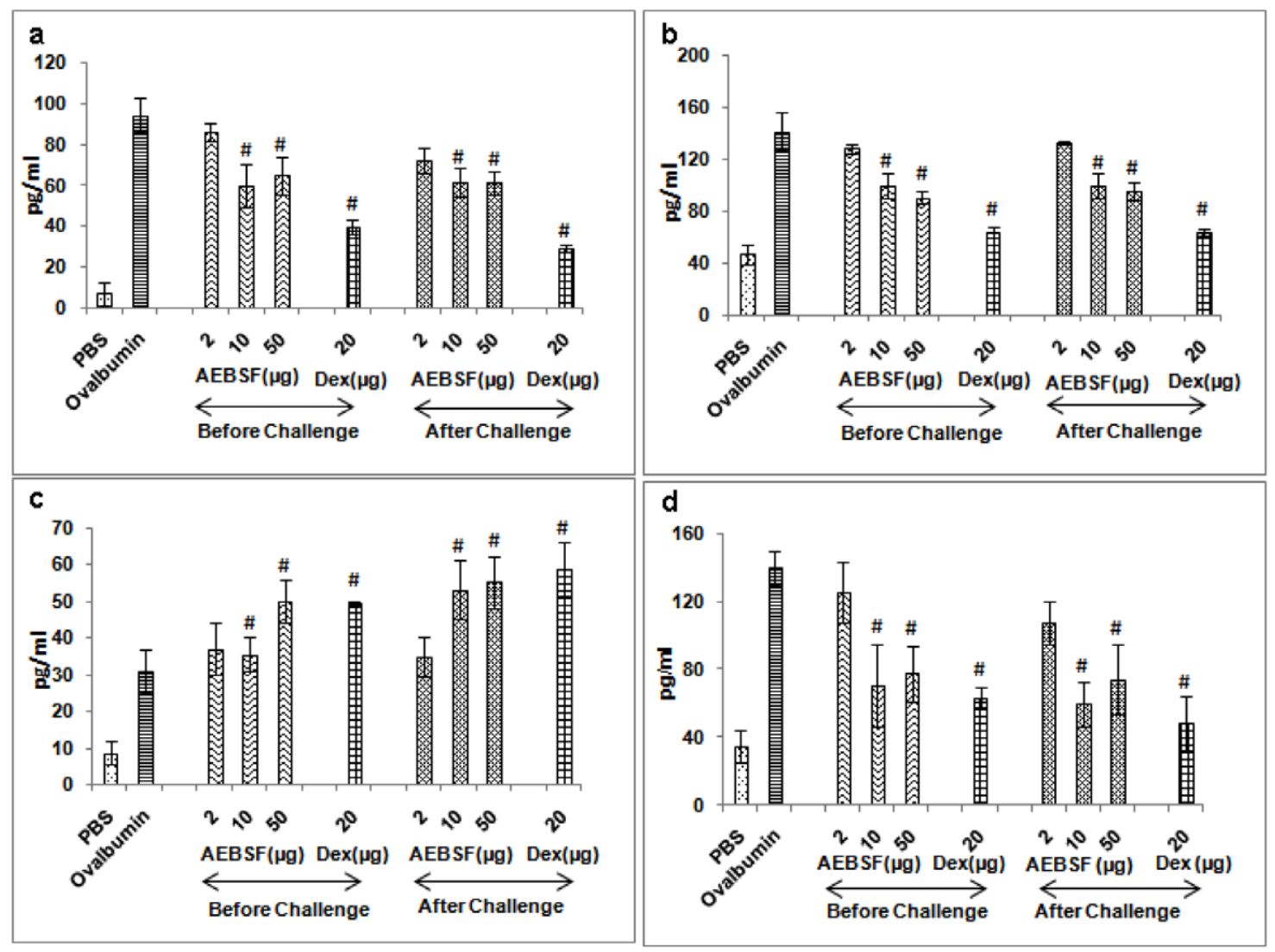

Figure 4. AEBSF/Dex treatment regulates cytokines. (a) IL-4, (b) IL-5, (c) IL-10 and (d) IL-13 level in BALF of ovalbumin challenged and AEBSF/ Dex treated groups of mice. Results are in mean \pm SD of 6 mice per group for one of the two independent mice experiments. \#: $p<0.05$. doi:10.1371/journal.pone.0041107.g004

stained lung sections revealed that AEBSF treated mice showed reduced goblet cell hyperplasia (Figure 6a-h) as compared to ovalbumin sensitized mice (Figure 6j) indicating low mucus production.

\section{Reduction in Cysteinyl Leukotrienes Level in BALF by AEBSF Treatment}

The Cys-LT level in BALF of mice with different doses of AEBSF treatment and dexamethasone are presented in Figure 7. All the doses of AEBSF (2 to $50 \mu \mathrm{g}$ ) and dexamethasone were effective in reducing Cys-LT level, significantly in after challenge groups whereas only $50 \mu \mathrm{g}$ dose could significantly reduce the Cys-LT level in before challenge treatment group.

\section{AEBSF Treatment Reduces 8-isoprostane}

To determine the oxidative stress, 8-isoprostane level was measured in BALF by ELISA. Analysis of results revealed that the treatment with $10 \mu \mathrm{g}$ of AEBSF suppresses the oxidative stress significantly before and after ovalbumin challenge than ovalbumin group mice (Figure 8). Dexamethasone also reduced the oxidative stress marker 8-isoprostane level in BALF significantly.

\section{Discussion}

Asthma is a disease of multifunctional etiology where allergens play a significant role in exacerbation of the symptoms. Most asthma cases are allergic in origin. Studies show that proteases derived from diverse sources are important allergens [20-23]. Earlier studies suggest that the protease load in human airways increase significantly following allergen exposure [24] that leads to protease antiprotease imbalance at the respiratory mucosal surfaces [25,26]. This increase in proteolytic activity contributes to airway pathophysiology as well as airway remodeling associated with the asthma. In the present study, preventive and therapeutic effects of a protease inhibitor, AEBSF was investigated in ovalbumin induced mouse model of allergic airway disease.

Previously, a tryptase inhibitor APC366 reduced IgE and non$\mathrm{IgE}$ mediated histamine release from mast cells [27,28]. Tryptase inhibitor MOL 6131 inhibited release of Th2 cytokines in mouse model [29]. Further, serine protease inhibitors-nefamostat mesilate and gabexate mesilate suppressed Der $\mathrm{p}$ induced allergic response, when given during sensitization and after challenge [30]. In the present study, AEBSF treatment was given in sensitized mice, which is clinically relevant for patients. Mice were given intranasal treatment to limit the effect of protease inhibitor on affected tissue and to avoid possible side effects. The dose of AEBSF treatment in the present study was determined by preliminary experiment.

In the present study, repeated exposure with ovalbumin induced Th2 milieu in mice with subsequent increase in serum $\operatorname{IgE}$ and IgG1 and cytokines like IL-4 IL-5 and IL-13 in BALF. AEBSF treatment showed significant reduction in $\mathrm{IgE}$ with higher dose in both before and after antigen challenge treatment groups. IgG1 titer also reduced significantly in both treatment groups of mice at $10 \mu \mathrm{g}$ and $50 \mu \mathrm{g}$ dose of AEBSF. IL-4, IL-5 and IL-13 levels decreased on treatment with AEBSF, whereas IL-10 level increased significantly with $50 \mu \mathrm{g}$ dose of AEBSF. Studies with SLPI [31], nefamostat mesilate and gabexate mesilate induced IL10 that has suppressed allergen induced airway inflammation [32]. 

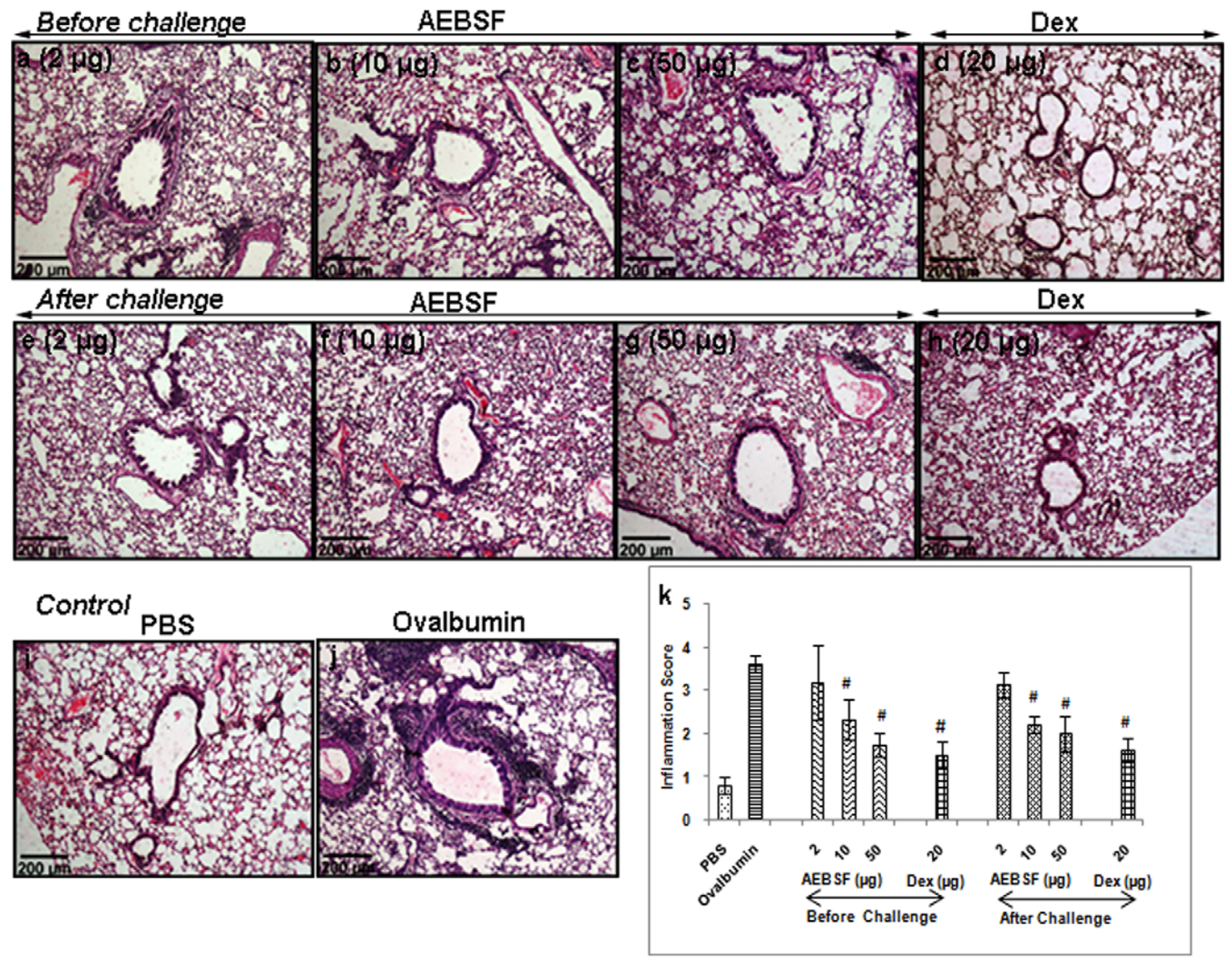

Figure 5. Lung sections of mice stained with H\&E (10X). (j) Lung sections indicating cellular infiltration in airways due to ovalbumin sensitization and challenge. (a-h) AEBSF treatment reduces the infiltration of cells. (k) Inflammation score of AEBSF/Dex treated ovalbumin sensitized mice presented as mean \pm SD of 6 mice per group for one of the two independent mice experiments. \#: $p<0.05$. doi:10.1371/journal.pone.0041107.g005

$\mathrm{IgE}$ cross linking with allergen degranulates mast cells and basophils releasing tryptase and proinflammatory mediators. Tryptase is a known inducer of eosinophil and neutrophil infiltration [33]. These cells are involved in late phase allergic reactions and produce peroxidase that degrades self tissue and increases oxidative burden [34]. The present data demonstrate increased proteolytic activity in BALF of ovalbumin challenged mice and AEBSF treatment reduced cellular infiltration and proteolytic/peroxidase activity.

Allergen activates inflammatory cells to release inflammatory mediators including cysteinyl leukotrienes [35] that induces bronchoconstriction [36] and mucus production [37]. AEBSF treatment reduced $(50 \mu \mathrm{g}$ before $/ 2-50 \mu \mathrm{g}$ after challenge treatment) the Cys-LT level in BALF indicating its therapeutic potential. Histology of lung tissue also showed decreased cellular infiltration in AEBSF treated mice. This led to significant reduction $(p<0.05)$ in inflammation score compared to ovalbumin control group. This is in accordance with an earlier study where nefamostat mesilate and gabexate mesilate were used as inhibitors [38].

In asthma, the balance between oxidants and antioxidants in the airways is altered, leading to the excessive production of ROS [39]. ROS enhances the production of lipid derivatives such as 8isoprostane which induces contraction in airway smooth muscle cells in vitro [40]. AEBSF treatment in before challenge group $(10 \mu \mathrm{g})$ and in after challenge group $(2 \mu \mathrm{g}$ and $10 \mu \mathrm{g})$ showed significant decrease in 8-isoprostane level in BALF. This is in agreement with the previous studies showing inhibition of NADPH oxidase, a key enzyme that catalyses the ROS production in phagocytes by AEBSF [41]. Besides, AEBSF is known to induce the expression of heme oxigenase I via protein kinase B pathway. Heme oxigenase degrades the pro-oxidant heme and produces anti-oxidant bilirubin which further provides cellular protection against oxidative stress [42]. AEBSF inhibits NADPH oxidase and reduces superoxide production [43]. It also inhibits the invasion of parasites in vitro [44] and attenuate vasogenic brain edema formation in newborn pigs [45].

Although both the treatment protocols were effective in reducing airway inflammation, therapeutic treatment reduced inflammation, Cys-LT and oxidative stress more effectively than the prophylactic treatment. AEBSF reduced the IL-5 levels in dose dependent manner in both protocols.

Current therapies for asthma mainly include use of corticosteroids, and short- and long-acting $\beta 2$ adrenergic receptor agonists, based on the severity of the symptoms. Although these therapies are effective in providing symptomatic relief, none of the therapies are curative. Also the use of oral steroids for long terms showed undesirable side effects. Serine protease inhibitors are regarded as potential therapeutic option to reduce the use of steroid in airway inflammatory diseases. In conclusion, AEBSF significantly reduces allergic airway inflammation and has potential for adjunct therapy in allergic diseases including asthma. 

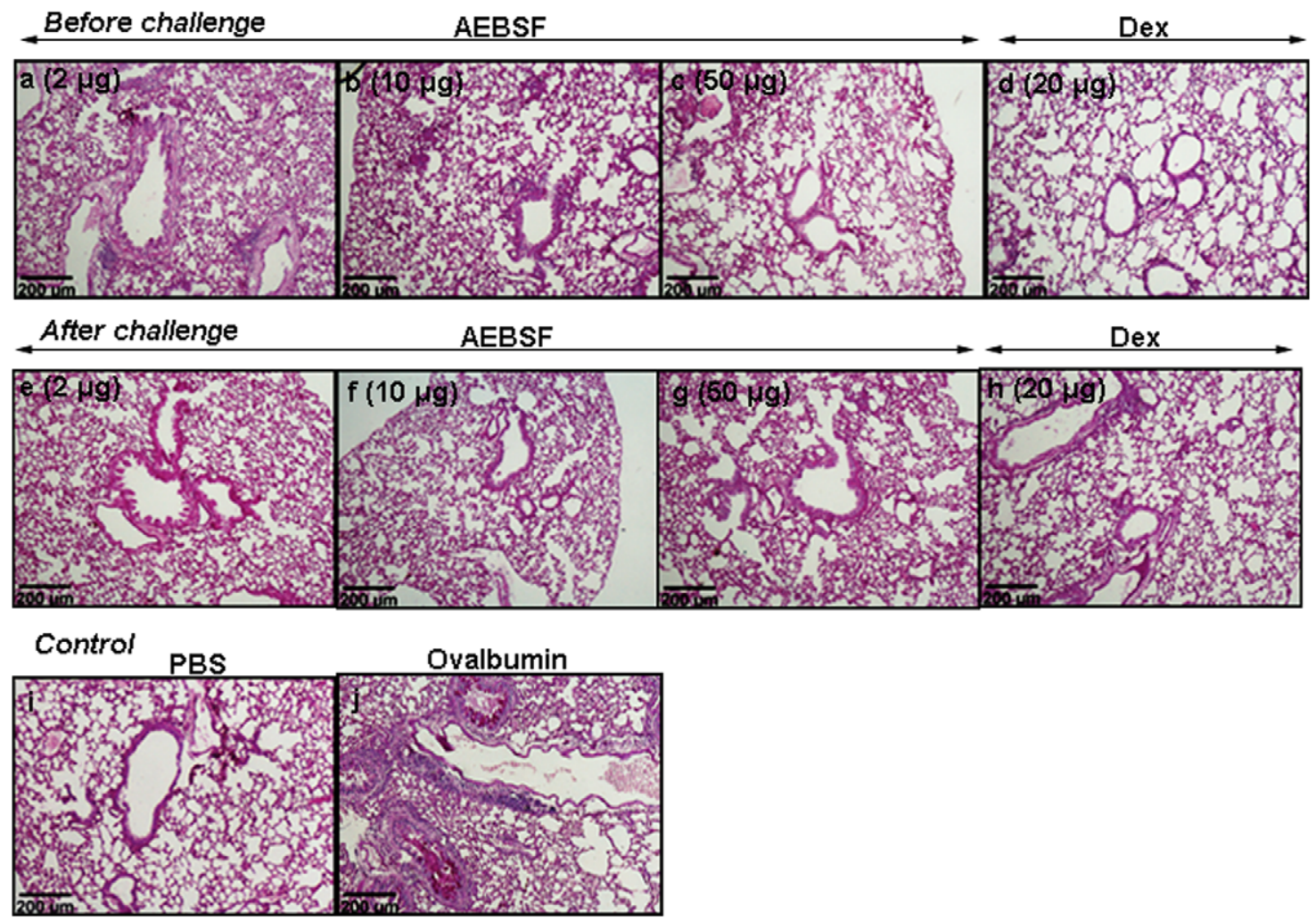

Figure 6. PAS stained lung tissue section (10X). (j) The goblet cell hyperpalesia was identified by magenta coloured stain inside the lumen in ovalbumin sensitized mice. (a-h) AEBSF/Dex treatment reduced the goblet cell hyperplasia in ovalbumin sensitized mice.

doi:10.1371/journal.pone.0041107.g006

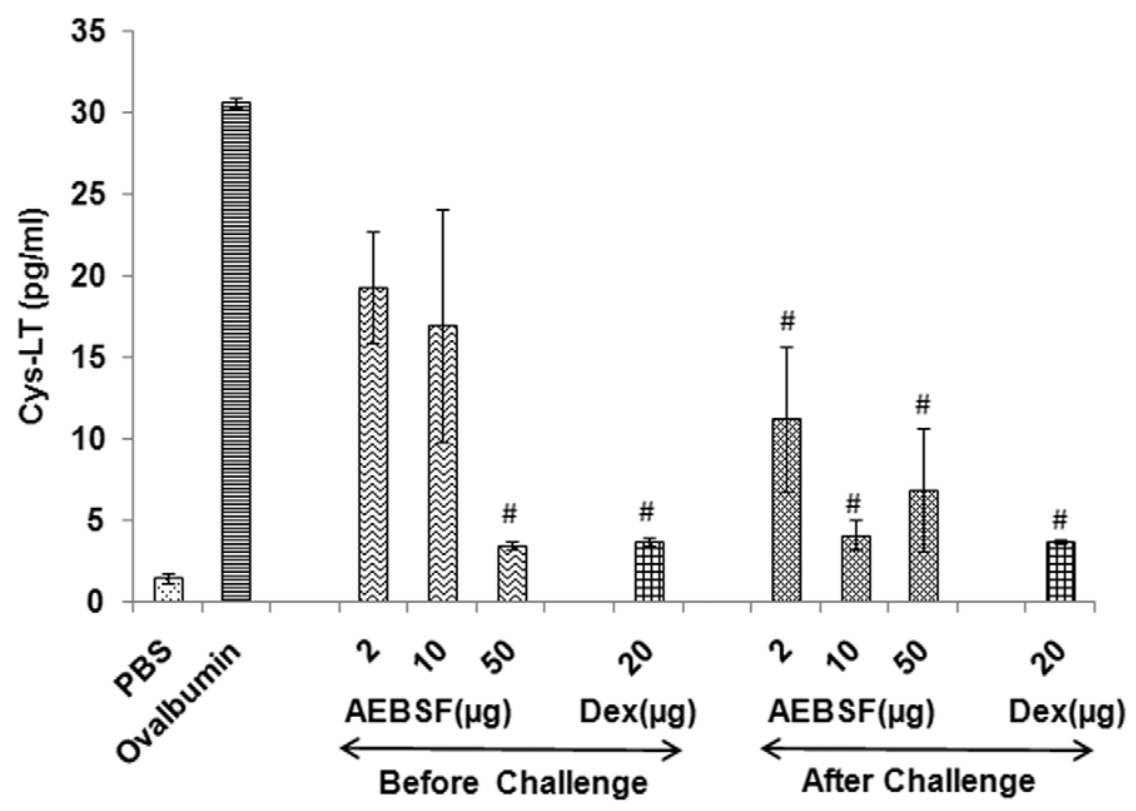

Figure 7. AEBSF/Dex treatment lowers Cys-LT in BALF. Cys-LT levels in BALF of ovalbumin sensitized and AEBSF/Dex treated mice is presented as mean $\pm S D$ of 6 mice per group for one of the two independent mice experiments. \#: $p<0.05$. doi:10.1371/journal.pone.0041107.g007 


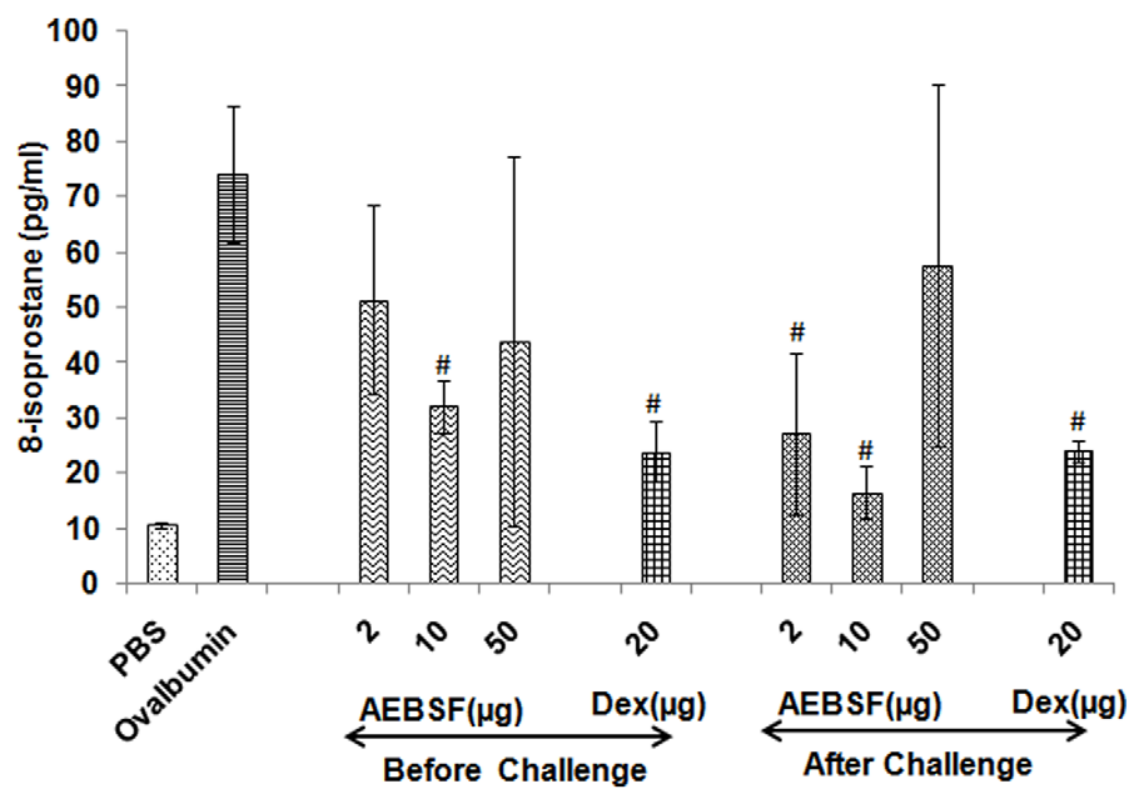

Figure 8. AEBSF/Dex treatment reduces oxidative stress. Oxidative stress was evaluated in terms of 8-isoprostane levels in BALF. Results are presented as mean \pm SD of 6 mice per group for one of the two independent mice experiments. \#: $p<0.05$. doi:10.1371/journal.pone.0041107.g008

\section{Materials and Methods}

\section{Animal and Ethics}

Female BALB/c mice of 6-8 weeks weighing 18-22 grams were procured from Central Drug Research Institute, Lucknow (India). Mice were housed for 2 weeks to get acclimatized to experimental conditions. Standard chow diet (ad labitum) and purified water were provided to mice, kept at $40-70 \%$ humidity with 12 hour controlled light: dark cycle. All the experimental procedures were carried out in the morning to minimize the effect of circadian rhythm. The animal experiment was repeated twice and the results of one of the two independent experiments are presented. The study protocol was approved by animal ethics committee of Institute of Genomics and Integrative Biology, Delhi.

\section{Immunization and Treatment Protocol}

Mice were divided into 10 groups randomly, containing 6 mice each and sensitized on day 0 and 14 by i.p. injection of $100 \mu \mathrm{g}$ ovalbumin adsorbed on $2 \mathrm{mg}$ alum. They were challenged with $2 \mu \mathrm{g}$ of ovalbumin on day 25,26 and 27 by i.n. route. Mice were treated with 2, 10 and $50 \mu \mathrm{g}$ of AEBSF (Sigma) i.n. 1 hour before or after ovalbumin challenge in groups. Dexamethasone $(20 \mu \mathrm{g})$ was given to the mice 1 hour before or after ovalbumin challenge through i.n route as treatment control. Intranasal treatment was given by anesthetizing mice with $3 \%$ isoflurane. One group of mice was treated with dexamethasone $(20 \mu \mathrm{g}) 1$ hour before challenge and another group $1 \mathrm{~h}$ after challenge. One group (negative control) of mice were sensitized, challenged and treated with PBS. Similarly a group of mice were sensitized/challenged with ovalbumin and treated with PBS.

\section{Sample Collection}

Mice were euthanized by i.p. injection of sodium thiopentone $(100 \mathrm{mg} / \mathrm{kg})$ on day 29 . BALF was collected from each mouse by instillation of $0.5 \mathrm{ml}$ of chilled PBS, thrice into the lung. BALF was centrifuged at $400 \mathrm{~g}$ for $10 \mathrm{~min}$ at $4{ }^{\circ} \mathrm{C}$ and supernatant was used for analysis of cytokines, leukotrines, 8-isoprostane and eosinophil peroxidase activity. Bronchoalveolar lavage cell pellet was used to determine cellular infiltration. Blood was collected, allowed to clot and sera were separated by centrifugation at $400 \mathrm{~g}$ for $10 \mathrm{~min}$. Lungs were incised from thoracic cavity of mice and fixed with $10 \%$ neutral-buffered formalin for histopathology.

\section{Eosinophil Count and Eosinophil Peroxidase Activity in BALF}

The bronchoalveolar lavage cell pellet was resuspended in PBS and total cell count per $\mathrm{ml}$ in BALF was determined using trypan blue (Sigma Aldrich Co., St. Luis, USA) and haemocytometer (Neuber's), under light microscope. Eosinophils were counted by staining BALF cell smear with Leishman stain. Percentage of eosinophils and neutrophils was determined by counting minimum of 200 cells. Absolute numbers of eosinophils and neutrophils in per $\mathrm{ml}$ of BALF were calculated by total cell counts and percentage value [46].

Eosinophil peroxidase activity was measured by spectrophotometric method. Briefly, $100 \mu \mathrm{l}$ of BALF supernatant from each sample was taken in microtitter plate in duplicates (Nunc-immuno, Denmark). One hundred microliter of substrate solution containing $0.1 \mathrm{mM}$ o-phenylene-diamine-dihydrochloride, $0.1 \%$ Triton $\mathrm{X}-100$ and $1 \mathrm{mM}$ hydrogen peroxide in $0.05 \mathrm{M}$ Tris- $\mathrm{HCl}$ was added in each well and incubated for $30 \mathrm{~min}$ at $37^{\circ} \mathrm{C}$. Reaction was stopped by adding $50 \mu \mathrm{l}$ of $4 \mathrm{M}$ sulphuric acid. Absorbance was measured at $492 \mathrm{~nm}$ using microplate spectrophotometer reader (Bio-Rad Laboratories Ltd., UK). EPO activity of BALF supernatant was depicted in the term of OD per min per mg of protein [47].

\section{Proteolytic Activity in BALF of Mice}

To evaluate proteolytic activity in BALF, azo dye impregnated collagen (Sigma Aldrich) was used as a substrate. Ten milligram of substrate in $1 \mathrm{ml}$ Tris-HCl buffer $(\mathrm{pH} \mathrm{6.5)}$ was incubated with $20 \mu \mathrm{l}$ of $\mathrm{BALF}$ at $37^{\circ} \mathrm{C}$. After $60 \mathrm{~min}$ incubation at constant shaking of $200 \mathrm{rpm}, 4 \%$ trichloroacetic acid was added to stop the reaction. Mixture was centrifuged and absorbance was measured 
at $520 \mathrm{~nm}$ [48]. One unit of specific activity was defined as 1.00 changes in absorbance per microgram of protein per hour [49].

\section{Measurement of Ovalbumin Specific Antibodies in Sera of Mice}

Relative concentrations of ovalbumin specific IgE, IgGl and IgG2a were measured in serum samples of mice by indirect ELISA [46]. Briefly, microtiter plates (Nunc-Immuno, Denmark) were coated with $500 \mathrm{ng}$ ovalbumin/well in $100 \mu \mathrm{l}$ of $0.1 \mathrm{M}$ carbonate buffer (pH 9.6) and incubated overnight at $4{ }^{\circ} \mathrm{C}$. After washing with PBS, plates were blocked with $3 \%$ defatted milk for $3 \mathrm{~h}$ at 37 ${ }^{\circ} \mathrm{C}$. Sera samples were diluted in PBS 1:10, 1:50 and 1:50 v/v for $\mathrm{IgE}, \mathrm{IgGl}$ and $\mathrm{IgG} 2 \mathrm{a}$, respectively and used in triplicates for estimation. In each well, $100 \mu \mathrm{l}$ of diluted sera was added and the plates were incubated overnight at $4{ }^{\circ} \mathrm{C}$. Unbound antibodies were removed by washing the plates with PBST $(0.05 \%$ Tween- 20 in PBS) and subsequently incubated for $3 \mathrm{~h}$ at $37^{\circ} \mathrm{C}$ with anti-mouse IgG1-peroxidase or anti-mouse IgG2a-peroxidase (1:1000 PBS; BD Pharmingen, San Diego, CA, USA). For IgE estimation, the plate was incubated with biotinylated anti-mouse $\operatorname{IgE}(2 \mu \mathrm{g} / \mathrm{mL}$, BD Pharmingen) at $25^{\circ} \mathrm{C}$ for $90 \mathrm{~min}$ followed by streptavidinperoxidase (1:1000; BD Pharmingen) for $30 \mathrm{~min}$. After washing, plates were developed using o-phenylenediamine and absorbance was read at $492 \mathrm{~nm}$.

\section{Estimation of Cytokines in BALF}

Cytokines IL-4, IL-5, IL-10 (BD Pharmingen, USA and R \& D, MN, USA) and IL-13 (R\&D Systems Minneapolis, MN USA) were determined in BALF by ELISA following manufacturer's instructions. Briefly, $100 \mu \mathrm{l}$ capture antibody $(1: 250 \mathrm{v} / \mathrm{v})$ for each cytokine was coated separately in microtiter plates in carbonate buffer, pH 9.6 (in phosphate buffer, pH 6.5 for IL-10 capture antibody) and incubated for 12 hour at $4{ }^{\circ} \mathrm{C}$. After washing with PBS, plates were blocked with assay diluent $(10 \%$ foetal bovine serum in PBS) at $25^{\circ} \mathrm{C}$ for $1 \mathrm{~h}$. Plates were washed with PBS and $100 \mu \mathrm{l}$ of standards (seven serial dilutions) and undiluted BALF samples were added to the wells in duplicates. After incubation at $25^{\circ} \mathrm{C}$ for $2 \mathrm{~h}$, the plates were washed and incubated with biotinylated detector antibody labeled with avidin-horse radish peroxidise (HRP) at $25^{\circ} \mathrm{C}$ for $1 \mathrm{~h}$. After washing, $100 \mu \mathrm{lof}$ tetramethylbenzidine (Sigma Aldrich) substrate solution was added in each well and developed by incubating at $37^{\circ} \mathrm{C}$ in dark. Reaction was stopped by addition of $4 \mathrm{~N} \mathrm{H}_{2} \mathrm{SO}_{4}$ and absorbance was measured at $450 \mathrm{~nm}$ (wavelength correction at $570 \mathrm{~nm}$ ) using microplate reader (Bio-Rad).

\section{Cysteinyl Leukotrienes Levels in BALF}

Cysteinyl leukotriene (Cys-LT) levels were determined in BALF using enzyme immunoassay kit (Cayman Chemical Co. MI, USA). Briefly, $50 \mu \mathrm{l}$ of standards (8 serial dilutions) or BALF was added

\section{References}

1. Gupta R, Sharma V, Sridhara S, Singh BP, Arora N (2004) Identification of serine protease as a major allergen of Curvularia lunata. Allergy 59: 421-427.

2. Koblinski JE, Ahram M, Sloane BF (2000) Unraveling the role of proteases in cancer. Clin Chim Acta 291: 113-135.

3. Sudha VT, Arora N, Gaur SN, Pasha S, Singh BP (2008) Identification of a serine protease as a major allergen (Per a 10) of Periplaneta americana. Allergy 63: $768-776$.

4. Reed CE, Kita H (2004) The role of protease activation of inflammation in allergic respiratory diseases. J Allergy Clin Immunol 114: 997-1008.

5. Hewitt CR, Foster S, Phillips C, Horton H, Jones RM, et al. (1998) Mite allergens: significance of enzymatic activity. Allergy 53: 60-63.

6. Shen HD, Lin WL, Tam MF, Wang SR, Tzean SS, et al. (1999) Characterization of allergens from Penicillium oxalicum and $P$. notatum by per well of microtiter plates in duplicates. To this, $50 \mu \mathrm{l}$ of tracer and $50 \mu \mathrm{l}$ of Cys-LT antiserum was added and incubated at $25^{\circ} \mathrm{C}$ for $18 \mathrm{~h}$. Following washing with buffer, plate was developed by adding Ellman's reagent and incubating in dark at $25^{\circ} \mathrm{C}$ for $1.5 \mathrm{~h}$. Absorbance was read periodically at $420 \mathrm{~nm}$.

\section{Measurement of Oxidative Stress}

The level of 8-isoprostane in BALF was measured using enzyme immunoassay kit (Cayman Chemical) following the manufacturer's instructions. Briefly, standards in different dilutions and BALF samples were mixed ( $50 \mu \mathrm{l} /$ well) with $50 \mu \mathrm{l}$ of 8-isoprostane tracer and $50 \mu \mathrm{l}$ of 8-isoprostane antiserum and then incubated at $4{ }^{\circ} \mathrm{C}$ for $18 \mathrm{~h}$. After washing with wash buffer, $100 \mu \mathrm{l}$ of substrate solution was added to each well and incubated in dark at $25^{\circ} \mathrm{C}$ for 90 min with gentle shaking. Absorbance was read periodically at $420 \mathrm{~nm}$ until the absorbance of maximum binding wells reached a minimum of 0.3 A.U (Absorbance unit).

\section{Histopathology}

The lungs were embedded in paraffin and sections of $4 \mu \mathrm{m}$ thickness were cut and stained with haematoxylin and eosin. Histological evaluation was made under microscope $(10 \mathrm{X})$ and scored on the basis of cellular infiltration and narrowing of airway lumen. Using gridline the total square area around the lumen of airways has been counted and the percentage of square falling under the inflamed area had been evaluated and regarded as percentage affected area. And the scoring was made from 1-5. 'one' inflammatory reaction affecting $<20 \%$ of the airways, 'two' as $20-40 \%$ of the airways affected, 'three', $40-60 \%$, 'four', 60$80 \%$ and 'five', $>80 \%$ of the airways affected. Beside this figure of PAS stained lung section is included in manuscript.

\section{Statistical Analysis}

Statistical analysis of results was done by using GraphPad Prism and GraphPad Instat software (GraphPad Software, San Diego, CA, USA). The statistically significant difference was determined using one way ANOVA followed by Dunnett's multiple comparison tests between ovalbumin challenged and PBS treated and AEBSF treated mice groups. The $\mathrm{p}$ value $<0.05$ was considered as significant [46].

\section{Acknowledgments}

One of the authors (Sanjay Saw) is a 'Junior Research Fellow' from University Grant Commission, Delhi.

\section{Author Contributions}

Conceived and designed the experiments: SS NA. Performed the experiments: SS SLK. Analyzed the data: SS NA. Contributed reagents/ materials/analysis tools: NA. Wrote the paper: SS SLK NA.

immunoblotting and N-terminal amino acid sequence analysis. Clin Exp Allergy 29: 642-651.

7. Kauffman HF (2003) Interaction of environmental allergens with airway epithelium as a key component of asthma. Curr Allergy Asthma Rep 3: 101108.

8. Sudha VT, Arora N, Singh BP (2009) Serine protease activity of Per a 10 augments allergen-induced airway inflammation in a mouse model. Eur J Clin Invest 39: 507-516.

9. Goel C, Govindaraj D, Singh BP, Farooque A, Kalra N, et al. (2012) Serine protease Per a 10 from Periplaneta americana bias dendritic cells towards type 2 by upregulating CD86 and low IL-12 secretions. Clin Exp Allergy 42: 412-422.

10. Krishna MT, Chauhan A, Little L, Sampson K, Hawksworth R, et al. (2001) Inhibition of mast cell tryptase by inhaled APC 366 attenuates allergen-induced 
late-phase airway obstruction in asthma. J Allergy Clin Immunol 107: 10391045 .

11. Herbert CA, King CM, Ring PC, Holgate ST, Stewart GA, et al. (1995) Augmentation of permeability in the bronchial epithelium by the house dust mite allergen Der p1. Am J Respir Cell Mol Biol 12: 369-378.

12. Wan H, Winton HL, Soeller C, Tovey ER, Gruenert DC, et al. (1999) Der p 1 facilitates transepithelial allergen delivery by disruption of tight junctions. J Clin Invest 104: 123-133.

13. Schmidlin F, Amadesi S, Dabbagh K, Lewis DE, Knott P, et al. (2002) Proteaseactivated receptor 2 mediates eosinophil infiltration and hyperreactivity in allergic inflammation of the airway. J Immunol 169: 5315-5321.

14. Post S, Nawijn MC, Hackett TL, Baranowska M, Gras R, et al. (2011) The composition of house dust mite is critical for mucosal barrier dysfunction and allergic sensitisation. Thorax.

15. Balldin G, Ohlsson K, Balldin G, Ohlsson K (1979) Trasylol prevents trypsininduced shock in dogs. Hoppe Seylers Z Physiol Chem 360: 651-656.

16. Watanabe N, Tomimori Y, Saito K, Miura K, Wada A, et al. (2002) Chymase inhibitor improves dermatitis in NC/Nga mice. Int Arch Allergy Immunol 128: 229-234.

17. Imada T, Komorita N, Kobayashi F, Naito K, Yoshikawa T, et al. (2002) Therapeutic potential of a specific chymase inhibitor in atopic dermatitis. Jpn J Pharmacol 90: 214-217.

18. Tomimori Y, Tsuruoka N, Fukami H, Saito K, Horikawa C, et al. (2002) Role of mast cell chymase in allergen-induced biphasic skin reaction. Biochem Pharmacol 64: 1187-

19. Izakovicova HL, Kankova K, Znojil V (2009) Haplotype analysis of the NADPH oxidase p22 phox gene in patients with bronchial asthma. Int Arch Allergy Immunol 148: 73-80.

20. Shen HD, Tam MF, Tang RB, Chou H (2007) Aspergillus and Penicillium allergens: focus on proteases. Curr Allergy Asthma Rep 7: 351-356.

21. Bisht V, Arora N, Singh BP, Pasha S, Gaur SN, et al. (2004) Epi p 1, an allergenic glycoprotein of Epicoccum purpurascens is a serine protease. FEMS Immunol Med Microbiol 42: 205-211.

22. Tripathi P, Kukreja N, Singh BP, Arora N (2009) Serine protease activity of Cur 11 from Curvularia lunata augments Th2 response in mice. J Clin Immunol 29: 292-302.

23. Gough L, Schulz O, Sewell HF, Shakib F (1999) The cysteine protease activity of the major dust mite allergen Der p 1 selectively enhances the immunoglobulin E antibody response. J Exp Med 190: 1897-1902.

24. Wenzel SE, Fowler AA III, Schwartz LB (1988) Activation of pulmonary mast cells by bronchoalveolar allergen challenge. In vivo release of histamine and tryptase in atopic subjects with and without asthma. Am Rev Respir Dis 137: 1002-1008.

25. Simpson JL, Scott RJ, Boyle MJ, Gibson PG (2005) Differential proteolytic enzyme activity in eosinophilic and neutrophilic asthma. Am J Respir Crit Care Med 172: 559-565.

26. Inoue K, Takano H, Yoshikawa T (2005) Protease-antiprotease imbalance in inflammatory diseases in the lung. Chest 128: 1069.

27. He S, Gaca MD, Walls AF (1998) A role for tryptase in the activation of human mast cells: modulation of histamine release by tryptase and inhibitors of tryptase. J Pharmacol Exp Ther 286: 289-297.

28. He S, Gaca MD, Walls AF (2001) The activation of synovial mast cells: modulation of histamine release by tryptase and chymase and their inhibitors. Eur J Pharmacol 412: 223-229.

29. Oh SW, Pae CI, Lee DK, Jones F, Chiang GK, et al. (2002) Tryptase inhibition blocks airway inflammation in a mouse asthma model. J Immunol 168: 19922000.

30. Chen CL, Wang SD, Zeng ZY, Lin KJ, Kao ST, et al. (2006) Serine protease inhibitors nafamostat mesilate and gabexate mesilate attenuate allergen-induced airway inflammation and eosinophilia in a murine model of asthma. J Allergy Clin Immunol 118: 105-112.
31. Sano C, Shimizu T, Sato K, Kawauchi H, Tomioka H (2000) Effects of secretory leucocyte protease inhibitor on the production of the antiinflammatory cytokines, IL-10 and transforming growth factor-beta (TGF-beta), by lipopolysaccharide-stimulated macrophages. Clin Exp Immunol 121: 77-85.

32. Tournoy KG, Kips JC, Pauwels RA, Tournoy KG, Kips JC, et al. (2000) Endogenous interleukin-10 suppresses allergen-induced airway inflammation and nonspecific airway responsiveness. Clin Exp Allergy 30: 775-783.

33. He S, Walls AF (1997) Human mast cell tryptase: a stimulus of microvascular leakage and mast cell activation. Eur J Pharmacol 328: 89-97.

34. Saito K, Nagata M, Kikuchi I, Sakamoto Y (2004) Leukotriene D4 and eosinophil transendothelial migration, superoxide generation, and degranulation via beta2 integrin. Ann Allergy Asthma Immunol 93: 594-600.

35. Dahlen SE, Hedqvist P, Hammarstrom S, Samuelsson B, Dahlen SE, et al. (1980) Leukotrienes are potent constrictors of human bronchi. Nature 288: 484 486.

36. Liu YC, Khawaja AM, Rogers DF, Liu YC, Khawaja AM, et al. (1998) Effects of the cysteinyl leukotriene receptor antagonists pranlukast and zafirlukast on tracheal mucus secretion in ovalbumin-sensitized guinea-pigs in vitro. Br J Pharmacol 124: 563-571.

37. Ishizaki M, Tanaka H, Kajiwara D, Toyohara T, Wakahara K, et al. (2008) Nafamostat mesilate, a potent serine protease inhibitor, inhibits airway eosinophilic inflammation and airway epithelial remodeling in a murine model of allergic asthma. J Pharmacol Sci 108: 355-363.

38. Nadeem A, Masood A, Siddiqui N (2008) Oxidant-antioxidant imbalance in asthma: scientific evidence, epidemiological data and possible therapeutic options. Ther Adv Respir Dis 2: 215-235.

39. Kawikova I, Barnes PJ, Takahashi T, Tadjkarimi S, Yacoub MH, et al. (1996) 8Epi-PGF2 alpha, a novel noncyclooxygenase-derived prostaglandin, constricts airways in vitro. Am J Respir Crit Care Med 153: 590-596.

40. Megyeri P, Pabst KM, Pabst MJ (1995) Serine protease inhibitors block priming of monocytes for enhanced release of superoxide. Immunology 86: 629-635.

41. Wijayanti N, Kietzmann T, Immenschuh S (2005) Heme oxygenase-1 gene activation by the $\mathrm{NAD}(\mathrm{P}) \mathrm{H}$ oxidase inhibitor 4-(2-aminoethyl) benzenesulfonyl fluoride via a protein kinase B, p38-dependent signaling pathway in monocytes. J Biol Chem 280: 21820-21829.

42. Diatchuk V, Lotan O, Koshkin V, Wikstroem P, Pick E, et al. (1997) Inhibition of NADPH oxidase activation by 4 -(2-aminoethyl)-benzenesulfonyl fluoride and related compounds. J Biol Chem 272: 13292-13301.

43. Conseil V, Soete M, Dubremetz JF, Conseil V, Soete M, et al. (1999) Serine protease inhibitors block invasion of host cells by Toxoplasma gondii. Antimicrob Agents Chemother 43: 1358-1361.

44. Megyeri P, Nemeth L, Pabst KM, Pabst MJ, Deli MA, et al. (1999) 4-(2Aminoethyl)benzenesulfonyl fluoride attenuates tumor-necrosis-factor-alphainduced blood-brain barrier opening. Eur J Pharmacol 374: 207-211.

45. Nakamura Y, Hoshino M, Sim JJ, Ishii K, Hosaka K, et al. (1998) Effect of the leukotriene receptor antagonist pranlukast on cellular infiltration in the bronchial mucosa of patients with asthma. Thorax 53: 835-841.

46. Mehta AK, Gaur SN, Arora N, Singh BP (2007) Effect of choline chloride in allergen-induced mouse model of airway inflammation. Eur Respir J 30: 662671.

47. Kukreja N, Sridhara S, Singh BP, Arora N (2008) Effect of proteolytic activity of Epicoccum purpurascens major allergen, Epi p 1 in allergic inflammation. Clin Exp Immunol 154: 162-171.

48. Sudha VT, Arora N, Gaur SN, Pasha S, Singh BP (2008) Identification of a serine protease as a major allergen (Per a 10) of Periplaneta americana. Allergy 63: 768-776.

49. Zarnowski R, Connolly PA, Wheat LJ, Woods JP, Zarnowski R, et al. (2007) Production of extracellular proteolytic activity by Histoplasma capsulatum grown in Histoplasma-macrophage medium is limited to restriction fragment length polymorphism class 1 isolates. Diagn Microbiol Infect Dis 59: 39-47. 